\title{
ON THE DIFFERENCES BETWEEN THE LANGUAGE AND STYLE OF CZECH AND CZECH-AMERICAN PERIODICALS IN THE MID-19th CENTURY
}

\section{O RAZLIKAMA IZMEĐU JEZIKA I STILA ČEŠKE I ČEŠKO- AMERIČKE PERIODIKE SREDINOM 19. STOLJEĆA}

\author{
Alena Jaklová \\ Faculty of Arts, University of South Bohemia in České Budějovice, Czech Republic \\ Filozofski fakultet, Sveučilište Južne Češke, České Budějovice, Češka
}

\begin{abstract}
The paper deals with the language and style of major Czech and Czech-American periodicals published in the mid-19 ${ }^{\text {th }}$ century. Czech periodicals of the time are represented by the papers Pražský Posel and Národní Nowiny; the CzechAmerican ones include the weeklies Slowan Amerikánský and Národní Noviny. The language and style of both of these types of papers are analysed in order to identify the similarities and differences, with citations illustrating the phenomena explored. In this way, the research aims to show which aspects of the "stylistic norm" change first and most strikingly in a different language and national environment.
\end{abstract}

\section{INTRODUCTION}

The purpose of this study is to identify the characteristic features of the language and the style of periodicals (newspapers and magazines) published by Czech immigrants in the United States in the $2^{\text {nd }}$ half of the $19^{\text {th }}$ century and compare them with the language and style of those published roughly at the same time in their homeland, Bohemia. This comparison will then be used to demonstrate the general differences between the language of Czech expatriates and that used in their homeland in times before English became a language of universal
Sažetak

Rad se bavi jezikom i stilom glavnih čeških i češko-američkih časopisa objavljenih sredinom 19. stoljeća. Češka periodika toga doba zastupljena je u listovima Pražský Posel i Národní Nowiny; češko-američki uključuju tjednike Slowan Amerikánský i Národní Noviny. Analizira se jezik i stil obje skupine časopisa kako bi se identificirale sličnosti i razlike, a citati ilustriraju istraživane pojave. Na ovaj način, istraživanje ima za cilj pokazati koji se aspekti "stilske norme" mijenjaju prvo i najupečatljivije u drugom jezičnom i nacionalnom okruženju.

communication. It is well-known of media that, in addition to their informative, persuasive and entertaining functions $\mathbf{~} \mathbf{1}$ /, they have yet another characteristic feature: they capture standard language currently used and the ways of exploiting its potential, manifested in a particular linguistic make-up of texts and genres. These usually follow standard patterns in the media, which however, keep developing in time, changing along with the changes in the language of the community. 
II. THE OBJECT AND THE METHODOLGY OF RESEARCH

Immigrant periodicals fulfil a variety of functions: they inform, lead, instruct and educate the newcomers, and provide general orientation in an ethnically different environment. In the early days of life in a foreign country, their main roles are those of ethnic integration and identification. This is why the early immigrant periodicals (particularly in the first generation) are published in the mother tongue.

This was particularly true in the mid- $19^{\text {th }}$ century, when Czech immigrants started to leave for the USA on a mass scale /2/. A massive overseas exodus is a unique phenomenon in Czech history, both in terms of numbers and in its consequence: the rise and formation of a new ethnic community.

The earliest periodicals published in Czech in the USA date back to the early 1860s. The first of these was Slowan amerikánský, which started in Racine, Wisconsin, in 1860, followed by Národni noviny, first published in the same year in St. Louis, Missouri. In the summer of 1861 the two weeklies merged, producing a new periodical, also a weekly, called Slávie (initially published in Racine, later in Chicago). This paper would become a model for Czech-American journalism $/ \mathbf{3} /$.

Since the mid-19th century until the present, as many as 703 periodicals have been published in Czech. Now that the assimilation of Czech immigrants has long been completed, periodicals published by Americans with Czech roots are, with a few exceptions, exclusively in English and largely in the electronic format $/ 4 /$.

By comparing the language and the style of Czech and Czech-American periodicals from times before English became a language of worldwide communication, we will attempt to show which levels of language and stylistic norms /5/ (obviously far from being defined in the mid-19 ${ }^{\text {th }}$ century) are the ones to change first and most dramatically in a different language and national environment.

The source material for this comparison included, on the one hand, papers published in
Bohemia roughly in the mid-19 ${ }^{\text {th }}$ century Pražský Posel (PP) and Národní Nowiny (NNw), and, on the other hand, the early printed periodicals published roughly at the same time by immigrants to the USA: the weeklies Slowan Amerikánský (SA) and Národní Noviny (NN).

In order to compare the language and style of the Czech and Czech-American periodicals above, it is essential first to describe the principal characteristics of each of these separately, since there are noticeable differences even between Pražský Posel and Národní Nowiny, both published in Prague, and between Slowan Amerikánský and Národní Noviny, published overseas. Only then, on the basis of the results obtained through these analyses, can a general comparison be made between Czech and Czech-American periodicals.

\section{THE LANGUAGE AND STYLE OF CZECH PERIODICALS UNDER ANALYSIS}

Let us now proceed to the comparison of the language and style of the two Czech periodicals. First, however, note must be taken of the form of Czech used in the mid-19th century. As pointed out by M. Komárek /6/, the revolution year of 1848 and especially the fall of Bach's absolutism in 1859 represent milestones in the history of the Czech language. While language is always quick to respond to social changes, the beginning of the second half of the $19^{\text {th }}$ century saw changes in the very conditions for its development: Czech began to be used as the language of instruction at higher levels of education, the year 1882 marked the independence of the Czech section of Charles-Ferdinand University, Czech theatres were founded, Czech journalism thrived, the social basis for the development of standard Czech was widening, etc.

Journalism was experiencing rapid development as it aimed to respond to the interests of the general public in domestic and international affairs. This resulted in changes in the vocabulary (extension of scientific and technical terminology, loans from foreign languages, and also interventions into lexis by linguistic purists) and in grammar. Language norms dating back to the Humanistic period of the $16^{\text {th }}$ and the 
early $17^{\text {th }}$ centuries were gradually abandoned $/ 7 /$.

However, the development of journalism was far from smooth. In the 1850s the Czech press, which saw a promising period of rise in the revolution period, went into general decline. The number of papers dropped dramatically and the quality of those surviving deteriorated considerably. This unfortunate state can be attributed, among other factors, to a variety of regulations aimed especially against the opposition press and to the post-revolution political development. So in January 1850, following a temporary discontinuation, Národní Nowiny, owned and run by Karel Havlíček Borovský ceased to be published, followed by Pražský Posel in February 1851, edited by Josef Kajetán Tyl from 1846 till 1849. The persecution of Czech press continued until, in August 1851, there were only two political papers left: the government paper Pražské Noviny in Prague, and, under strict control, Moravské Noviny in Brno /8/.

The language and style of Pražský Posel, edited by Tyl, and those of Havlíček's Národní Nowiny show significant differences.

The first of these is related to Tyl's journalistic language /9/. Before outlining its principal features, it is important to understand the main objectives of the paper. Pražský Posel (subtitled Čtení pro lid jazyka českého, i.e. Reading for people of the Czech language) was meant not merely to inform, but also to explain and interpret, to win the readers' favour and to inspire them to take actions considered right and in line with the liberal faction within the national revival movement. This is why it uses simple language and, in order to persuade, creates the impression of contact with the readers, who are often addressed in the body of the text (the translation into English given in brackets only serves the purpose of illustrating the general meaning and cannot, owing to typological differences between Czech and English, capture some of the formal features of the original): Abych Vám, prátelé, na to zkrátka odpověděl - tedy řeknu, že to neni pravda. (To give you a brief answer, my friends - let me tell you that this is not true.) Elsewhere, readers are already addressed in the headline: Poslyšte prátelé! (Hear, my friends!).

Contact with the reader is simulated by the use of personal pronouns ([...] tedy vám také povím, že je část budoucí konstituce [...] již ponavržena a predložena, i.e. ([...] so I am also going to tell you that part of the future constitution [...] has already been formulated and submitted) and possessive pronouns (Obyvatelưm našich měst, i.e. To the inhabitants of our towns).

Overall, it can be said that, in his journalistic texts, Tyl often uses language devices described by V. Mathesius $/ \mathbf{1 0}$ / as creating a rhetorical perspective. The simplest of these is the use of the first person singular when the author refers to himself, and the second person plural when he turns to the readers. The latter is employed especially in passages (usually strongly expressive ones) appealing to the readers and prompting them to take action. As the presence of the author is clearly manifested in such passages, a kind of fictional dialogue is being established, e.g.

A protož, prátelé, rozpalte srdce své a upeoněte mysl svou! Ukažte, že jste Čechové, jimžto tak rádi "tvrdohlavcü" přezdívaji!! Ukažte svou tordou hlavu. Vždyt' jste povolovali dost dlouho, a jen ku své škodě, co se týče jazyka, a měli jste přec tam onde zákon pro sebe: stůjte jedenkráte vší silou na svém právu, kteréž je vám dáno slovem královým; tak vás nemůže nikdo pro to, že se honosite býti Čechy, zlostně stíhati a utiskovati! Jste národ svobodný - a když chcete, národ mocný! Sláva vám! (And therefore, friends, heat up your hearts and affirm your minds! Make it clear that you are Czechs, who are so often nicknamed "the strong-headed ones". Show your strong heads! You have been lenient long enough, and only to your detriment, as far as the language is concerned, and still you have abided by the law: hold for once tight to your right given to you by the word of the King; no one can persecute and oppress you in anger for showing proudly that you are Czechs! You are a free nation - and, if you will, a powerful one! Glory to you!) (PP, 1848, No. 3, p. 2) 
Tyl gives his texts a dramatic twist by asking a question and immediately answering it: Což by to bylo platné ríkat: Ty jsi svobodný občan - když by musel vykonávat, co na něj poddanství za minulých časủ uvalilo? Tedy se muselo zrušením poddanstó každému jindy poddanému občanu nejenom abych tak řekl, na duši ale i na těle ulehčit. (What good would there be in saying to someone: you are a free citizen - if he still had to do what the serfdom of past times imposed on him? So the abolition of serfdom must have relieved every subject, so to speak, not only in the mind, but also in the body.) (PP, 1848, No. 41, p. 1)

Although using standard language in his texts, Tyl often comes close to the norms of spoken language, for instance by frequently employing exclamatory, strongly expressive sentences and by including polyfunctional connecting devices and numerous instances of parenthesis, aposiopesis and ellipsis, as well as colloquial expressions, folk idioms, and frequent expressive words, e.g.

Nynčko; prej; a vida, už se povídá, že [...]; abych tak řekl; taková věc nenechá se jen tak z rukávu vytrepat; hanba, trojí hanba všem, kterých se tato zmínka týká!; Ba věru, nemilé!; Vida, vida! tedy mu boj nevoněl! (Now; supposedly; low and behold, a word is going the rounds that [...]; so to say; such a thing cannot just be conjured up; shame, triple shame on all concerned! Truly unwelcome! Oh, well! So, fighting was not his cup of tea!)

Although Tyl's style in Pražský Posel can be described as one of popular explication, characterised by clarity, coherence and comprehensibility, his language also draws on the humanistic tradition. This is manifested in word order (sentence-final position of the verb, postposition of congruent attributes), in the use of transgressive and passive constructions and, occasionally, in morphological archaisms, such as the pluperfect tense: [...], jak byl tento sněm ustanowil, i.e. [...], as the assembly had decreed (PP, 1948, No. 41, p. 323). Though rarely, Tyl still uses even periodic sentence structures.

Compared to Tyl, Havlíček's journalistic style can be described as more intellectual and academic. Havlíček is more conservative in his choice of language devices, drawing on the tradition of Czech of the Humanistic period. This is apparent not just in grammar (the morphology and syntax of the language of Národní Nowiny show all the relevant characteristics of the Humanistic (zech), but also in the lexis.

In terms of grammar, Havlíček relatively consistently employs the final position of finite verbs and periphrastic passive constructions, e.g.

Jest tomu již více než rok, co Ludvík Napoleon hlasem národu včelo francauzské republiky povolán byl, $i$ můžeme vším právem se tázati, co za celý čas učinil a pokud důvěry spoluobčanů svých hodným se stal. (More than a year has passed since Louis Napoleon, by the voice of the nation, was summoned to the head of the French Republic, and we can rightly ask what he has accomplished over the time and whether he has earned the trust of his fellow-citizens.) (NNw, 1850, No. 2, p. 1)

The lexis of Národní Nowiny is determined by the humanistic openness to adopting and using words from other languages, despite the fact that as early as the first half of the $19^{\text {th }}$ century, the principal emphasis in Czech journalism aiming at the general public was on comprehensibility and semantic unambiguity. Consequently, in addition to frequent lexical and grammatical Germanisms, Havlíček also employs a number of expressions from Romance languages, e.g. feuilleton; repertoir, bravourau; suprematie; mediatisace; precise; agitowati; protokoll; protokolista (NNw, 1850, No. 1 (2 January), p. 1-4), and specifically from Latin, e.g. casus beli; mystifikace; servilní; virtuos ( $\mathrm{NNw}$, 1850, No. 1 (2 January), p. 1-4). These examples occurred in the sources without any attempt by Havlíček to translate, paraphrase or explain them.

It is evident that Havlíček's language and style responded to the social development of the time: journalism extended its scope to include the higher social strata, and from the 1850s the papers were targeting mainly middle-class townsfolk readers, using a more advanced, 
syntactically archaic and relatively complex language employing an increasingly international lexis.

\section{THE LANGUAGE AND STYLE OF CZECH-AMERICAN PERIODICALS ANALYSED}

Let us now turn attention to Czech-American papers. When the early Czech immigrants started to arrive in the USA in the late 1840s, they brought with them a knowledge of standard Czech used in their home country in the first half of the $19^{\text {th }}$ century, which was rather conservative. Grammatically, it observed the norm codified by Dobrovský /11/,/12/, which in turn drew on the tradition of the much older classical period of Czech literature written in Humanistic Czech. The only component of the language that was changing was the lexis; at the beginning of the $19^{\text {th }}$ century, Czech vocabulary was expanding through new coinages and by loans from other, particularly Slavic, languages. As stated above, standard Czech did not start to develop rapidly in Bohemia until the second half of the $19^{\text {th }}$ century, reflecting the changing social and political circumstances.

This is manifested at all levels of the language of the Czech-American periodicals analysed, most profoundly in syntax. The traditional sentence structure of the Humanist period is preserved, with complex subordination clearly dominant in Slowan Amerikánský, while the language of Národní Noviny already employs less complex subordination, as well as coordination. The Czech-American press dating from the 1860s even contains periodic structures, predominantly again in Slowan Amerikánský, as in the extract from the article Staw republiky (The State of the Republic):

O prawe čisstolidsske a mrawne vzdělání sse nikdo nesstará: chudy pro nedostatek nemůže a bohaty sse jen tak dalece o vzdělání sstará, aby mohl chytrossti nabyti, které pak k obíraní chudého lidu a Evropanů používá! (No one cares about purely human and ethical education: the poor are prevented by their poverty, and the wealthy only care about education inasmuch as to become cunning enough to be able to rob poor people and the Europeans!) (SA 2, 1861, No. 24 (13 June), p. 1)

The early Czech-American papers employ another language device used frequently in the Humanistic period and occasionally also in Czech written texts of the first half of the $19^{\text {th }}$ century: the periphrastic passive construction, which was borrowed from Latin, as in the following extract from the article Nowá kompromis: Aby jižní konfederaci uznáno bylo, obchod otevřen a mír uzawřen byl; ktomu 500.000 dolarů co každoroční podpora na wydržowání wyssla kobraně proti cizímu nepřiteli na ně wypad činicímu, má od sseweru daná býti. (Jak krássná to wzpominka!). (In order that the southern confederation might be recognized, business opened and peace concluded; to this an annual maintenance subsidy of $\$ 500,000$ - for defence against attack by a foreign enemy - should be provided by the north. (What a beautiful memory!)) (SA 2, 1861, No. 27 (4 July), p. 1)

Similarly, the final position of the verb is employed most consistently in Slowan Ameriká$n s k y ́$, e.g. in the article Budoucnost moci pápežske a Napoleon 3ti (The future of papal power and $\mathrm{Na}$ poleon III):

Pakliže francouzsskym lisstum wěriti lze, tedy by pewnosst hirarchicke moci mnoho sset leteho panowání již na ssklonku byla. (If French papers are to be trusted, the fortress of hierarchical power of a hundred-year long rule would find itself close to its end.) (SA 2, 1861, No. 3 (31 January), p. 3)

Another characteristic of Slowan Amerikánský that appears conservative in the mid-19th century is the frequent use of transgressive participial constructions (including incongruent participle forms), e.g.

Tu jeden z nich zdwihna oči sswych ku hwězdnate obloze, s hluboka ssi wzdychnouc prawil: 'O Bože!' (Then one of them, having raised his eyes to the starry sky and having taken a deep breath, said: 'Oh Lord!') (SA 2, 1861, No. 5 (31 January), p. 3)

Intentional archaisation of the language of Czech-American periodicals is also apparent in

Coden: IORME7 
morphology, where the most frequent outdated elements include the use of the pluperfect tense, the nominal masculine genitive plural ending น̊v (20 dukátův), and also overuse of the nominative plural animate masculine ending -ové (jednatelowé, krajanowé) and extending it even to inanimate masculine nouns (národové, státové).

The new territorial, social and economic circumstances experienced by Czech immigrants in the USA, along with other factors, particularly the new cultural and communication context, affected the lexis of the early Czech-American periodicals more than all other levels of their language. The vocabulary of all of these periodicals is characterised by a number of loan words: Latinisms, Germanisms, and Americanisms.

In the first half of the $19^{\text {th }}$ century, Latin was the model of standard language for Czechs living both in their homeland and overseas, which is why lexical Latinisms occur in the Czech-American periodicals analysed. However, compared to journalistic texts published in Bohemia, and generally to the Czech language of the 1850s and 1860s, which the early Czech-American periodicals drew on prominently, their frequency is relatively low.

They were used by authors, often in a form adapted to conventions of Czech spelling and morphology, either without translation, e.g. akcent, compromis, disharmonie, furie, hystorie, ministeriá, praemie, partesy, or as terminological synonyms following in brackets their Czech equivalents, e.g. staré bajesloví pohanské (mythologie); poručení (mandat); prosebnice (siplikantky), rtut' (Merkurium), wyslysseni (audience), etc.

In contrast, the texts of the early Czech-American periodicals contain frequent Germanisms. Apparently, nearly all Czechs had a command of German and, moreover, in America they would settle down - and not just for reasons of language - close to German immigrants. Similarly, the early editors of Czech-American periodicals could all speak German, while very few spoke English. World news was therefore commonly obtained by translation from German sources, making the German-American press a considerable influence not only on the Czech papers and their language, but also on the Czech immigrant community.

However, lexical Germanisms are relatively rare in Czech immigrant texts; their Czech editors were probably aware of the purist tendencies in Bohemia and, in the atmosphere of the national revival, respected them. The texts analysed only contain examples like šanovat, batterie, punkty, škandal, spekulovat, koštovat, and a few others.

Substantially more common are semantic calques, which can be considered the most common type of German interference into Czech, e.g. trh na dobytek držeti se bude (Germ. den Viehmarkt abhalten); $k$ tomu ještě přijde, že [...] (Germ. dazu kommt noch, dass [...]).

The texts of the early Czech periodicals also abound in grammatical Germanisms; these also result from German interference in the Czech language of the early Czech-American speakers, and so they probably went unnoticed by the editors. They usually include grammatical calques, particularly prepositional and verbal structures modelled after German patterns, and regular use of the preposition skrz (through) replacing the instrumental case indicating the agent, as well as syntactic Germanisms.

The syntactic structure of German sentences served as a model for frequent infinitive constructions, determined the position of the infinitive within complex verb phrases and verbonominal structures, and resulted in the final position of finite verbs and the final position of definite modal verbs related to the infinitive. This also applies to the almost consistent final position of the past participle.

However, the most interesting lexical devices occurring in the early Czech-American periodicals are Americanisms. In spite of living under a sustained economic and social pressure from the dominant group in their new homeland, the first Czech immigrant generation kept rejecting

Coden: IORME7 
cultural and language assimilation. As they deliberately refused to learn English, the structure of their Czech was initially unaffected by it, but Americanisation was apparent in the ever-increasing use of lexical loans. The editors used English words where there was no suitable Czech equivalent or where they did not know one. Americanisms were also used in the Czech-American press because a frequent English word was semantically more appropriate in the new communicative situation. This applied to the names of various social organisations and institutions, company names, and local place names.

In the materials analysed, Americanisms proved to be most frequent in advertisements, particularly in Národní Noviny, but they can also be found in all other immigrant papers. They typically include English company and shop names, e.g. Peter's Music Store; Flora Garden; Arsenal Drug Store; Dry Good \& Clothing; Lager \& Bro.

The early Czech-American periodicals, particularly in their advertisement sections, already contain syntactic Americanisms, albeit not very frequently. The most common types include the position of the proper noun in the nominative case before the common noun, e.g. Na Soulard ulici druhý dům. (NN 2, 1861, No. 13 (13 April), p. 4); Uhel čtorté a Poplar ulice, or literal translation of English verbal constructions, often those employing prepositions, where the complementation differs in both languages, e.g. pro zoláštnosti poptej se, (blending two English prepositional constructions: to 'ask for st' and 'ask about st'); vlaky odchází Depot (in AmE 'trains leave the depot', where English uses the direct object without a preposition, while Czech uses the preposition $z$, i.e. from) /13/.

\section{A COMPARISON OF THE LANGUAGE AND STYLE OF CZECH AND CZECH- AMERICAN PERIODICALS PUBLISHED IN THE MID-19th CENTURY}

The results of comparison of the language and style of Czech and Czech-American papers published in the mid-19th century can briefly be summed up as follows:

The principal differences between Czech and immigrant periodicals are in their language, not in their style. Among them, Slowan Amerikánský most closely follows the tradition of Humanistic Czech, revived as the ideal language standard by Dobrovský in the early $19^{\text {th }}$ century. In Bohemia, this ideal of classicist Humanistic language, at all levels of language description, is more closely adhered to by Havlíček's Národní Nowiny than by Tyl's Pražský Posel. However, the reasons for using this rather complex language, including frequent internationalisms, are very different in the homeland compared to overseas (see above).

The reason why the language of the early Czech-American periodicals imitated the ideal of Humanistic Czech even more consistently, making them more conservative than the language of Czech periodicals of a decade before, is quite obvious: a separation from the "living current" of the mother tongue generally results in language competence freezing at the point of departure and eventually in decreasing verbal competence in the native language. A conscious effort to strictly observe the standards of literary Czech in America prompted the first generation of mid-19th-century editors to use as a model the "Kramerian" language /14/, highly praised by Dobrovský, which in turn drew on the older Weleslawinian language $/ \mathbf{1 5} /$, and was perceived as the superior communication tool in the first period of the Czech National Revival (the last third of the $18^{\text {th }}$ century to the mid-19th century).

As to the style of the periodicals, Slowan Amerikánský resembles Tyl's Pražský Posel in its exaggerated emotionality and frequent use of language devices simulating a two-way communication. These stylistic devices, complemented by frequent quotations of direct speech, are adopted into journalism from spoken language and are much more frequent in Slowan Amerikánský than all the other immigrant papers. 
What is the cause of these differences? The analysis suggests that the principal factors affecting the language and the style of the periodicals were the characters of the editors, their mental horizons, education and language competence. Comparing the style of Slowan Amerikánský and Národni Noviny on the one hand, and that of Pražský Posel and the Czech paper Národní Nowiny on the other, also means comparing the authorial styles of F. Koř́zek, J. B. Erben, J. K. Tyl and K. Havlíček Borovský, since it was primarily these editors who shaped their respective papers.

Nevertheless, the style of these periodicals was also co-determined by their focus - and in this they varied enormously.

While the early Czech-American periodicals were universal immigrant weeklies, their Czech counterparts were different. Pražský Posel of 1848 was a political weekly aiming at political education of ordinary people. Národní Nowiny was a political daily in which Havlíček laid the foundations of a modern concept of both foreign and home news processing and reporting. Of all differences between the language and style of the above-mentioned papers considered in their entirety, the most crucial one is the use in the Czech-American periodicals of lexical Americanisms. For the early immigrants, Czech initially remained their dominant language, living within Czech communities guaranteed that the range of its functions remained fully developed, and, consequently, relatively unaffected by English at all the respective levels of language description. On the other hand, the needs of everyday life in a different language environment, without a command of English, prevented successful participation in all the possible social and communicative situations, and this led to the rise of complementary bilingualism. The early stages of this process are reflected in the Czech-American periodicals of the time and manifested by gradual substitution of English expressions for Czech ones in an effort to capture the new American reality as accurately as possible.

It is to be noted that the above applies to the historical reality of the mid-19th century. The present Czech immigrants (if they consider themselves as such at all) leaving their homeland for the West are equipped with the command of the respective languages, stop using Czech in the new countries, and aim at assimilation (including language assimilation) into the receiving society within the shortest time possible.

\section{Notes}

/1/ From the perspective of media communication, media fulfil a range of functions: sociocultural, that of socialisation and orientation, interpretative, cognitive, entertaining and recreational, cf Jirák, J. and B. Köpplová, 2009; Pospíšil, J. and L. S. Závodná, 2009.

/2/ The period of mass Czech immigration to the USA can be dated between 1848 and 1914 .

/3/ Chada, J. (1981), The Czechs in the United States. New York: SVU Press 1981.

/4/ Jaklová, A. (2010), Čechoamerická periodika 19. a 20. století. Praha: Academia., p. 541-572.

/5/ The concept of stylistic norm is understood in Czech studies as a set of expressive devices characteristically employed in the production of texts within the respective functional styles. It can therefore be regarded as a kind of "model stylisation". (Nový encyklopedický slovník češtiny, 2016).

/6/ Komárek, M. (2012), Dějiny českého jazyka. Brno: Host.

/7/ Humanistic Czech is a term denoting a well-developed literary Czech language of the $16^{\text {th }}$ and the early $17^{\text {th }}$ centuries. In that period its grammatical structure underwent stabilisation and the scope of expressive devices, including style-specific ones, was expanding.

/8/ Beránková, M. (1970b ), HLAS, 1862 - 1865. Vznik, vývoj a politické zaměrení. Part I. Praha: Ústav pro teorii a dějiny hromadných sdělovacích prostředků Univerzity Karlovy v Praze.

19/ An earlier analysis of Tyl's language and style in Pražský Posel was undertaken by A. Stich, 1959.

/10/ Mathesius, V. (1982), Jazykozpytné poznámky k řečnické výstavbě souvislého výkladu. In: Jazyk, kultura, slovesnost. Praha: Odeon, p. 186-203.

/11/ Dobrovský, J. (1809), Ausführliches Lehrgebäude der Böhmischen Sprache. $1^{\text {st }}$ edition. vyd.

/12/ Dobrovský, J. (1819), Lehrgebäude der Böhmischen Sprache, zum Teile verkürzt, zum Teile umgearbeitet und vermehrt. $2^{\text {nd }}$ edition.

/13/ Jaklová, A., Smolka V. (2003), Jazyk současných čechoamerických žurnalistických textů. In: M. Čechová and D. Moldanová (eds.), Okraj a střed 
Alena Jaklová: ON THE DIFFERENCES BETWEEN THE LANGUAGE AND STYLE OF CZECH AND CZECH-AMERICAN PERIODICALS IN THE MID-19th CENTURY

Informatol. 54, 2021., 3-4

v jazyce a vliteratuře. Ústí nad Labem: Pedagogická fakulta UJEP, p. 182-192.

/14/ Beránková, M. (1970a), Počátky českého novinářství a jeho vývoj v době národního obrození. Praha: Státní pedagogické nakladatelství.
/15/ Havránek, B. (1979), Vývoj českého spisovného jazyka. Praha: Státní pedagogické nakladatelství. 